\title{
MIR516A2 wt Allele
}

National Cancer Institute

\section{Source}

National Cancer Institute. MIR516A2 wt Allele. NCI Thesaurus. Code C82202.

The human MIR516A2 wild-type allele is located in the vicinity of $19 q 13.41$ and is approximately 90 bases in length. This allele, which encodes MIR516A2 pre-miRNA, plays a role in the regulation of gene expression. Alteration in the expression of this gene is associated with development of breast cancer. 